University of Nebraska - Lincoln

DigitalCommons@University of Nebraska - Lincoln

$12-22-2017$

FORGOTTEN AULACOTHORAX BOHEMAN, 1858, A SENIOR

SYNONYM OF ORTHALTICA CROTCH, 1873 (COLEOPTERA:

CHRYSOMELIDAE: GALERUCINAE: ALTICINI)

Jan Bezdek

Alexander S. Konstantinov

Follow this and additional works at: https://digitalcommons.unl.edu/usdaarsfacpub

This Article is brought to you for free and open access by the U.S. Department of Agriculture: Agricultural Research Service, Lincoln, Nebraska at DigitalCommons@University of Nebraska - Lincoln. It has been accepted for inclusion in Publications from USDA-ARS / UNL Faculty by an authorized administrator of DigitalCommons@University of Nebraska - Lincoln. 


\title{
Forgotten Aulacothorax Boheman, 1858, a Senior Synonym of Orthaltica Crotch, 1873 (Coleoptera: Chrysomelidae: Galerucinae: Alticini)
}

\author{
JAN BEZDĚK \\ Mendel University, Department of Zoology \\ Zemědělská 1, 61300 Brno, CZECH REPUBLIC \\ bezdek@mendelu.cz
}

AND

AleXANDER S. Konstantinov

Systematic Entomology Laboratory, ARS, USDA

c/o National Museum of Natural History, Smithsonian Institution

P.O. Box 37012, MRC-168

Washington, DC 20013-7012, USA

alex.konstantinov@ars.usda.gov

\begin{abstract}
Discovery of the holotype of Aulacothorax exilis Boheman, 1858, originally described in Scydmaeninae (Staphylinidae), in the collections of Naturhistoriska Riksmuseet Stockholm in Sweden revealed that this species is actually a leaf beetle (Chrysomelidae) belonging to the genus until now known as Orthaltica Crotch, 1873. Because Aulacothorax has been available since 1858 and Orthaltica only since 1873, we here synonymize Orthaltica with Aulacothorax. Aulacothorax exilis is redescribed and illustrated.
\end{abstract}

Key Words: taxonomy, senior synonym, leaf beetles, Boheman, Tahiti

DOI.org/10.1649/0010-065X-71.4.791

Zoobank.org/urn:1sid:zoobank.org:pub:40526675-8A33-4AD6-92C4-590EABFA2D03

The Swedish frigate "Eugenie" conducted a voyage around the world in the years 1851-1853. Several naturalists on board acummulated large collections of animals and plants from various localities, and the scientific results of the voyage were published in the three-volume publication "Kongliga Svenska Fregatten Eugenies Resa omkring jorden under befäl af C. A. Virgin, ären 1851-1853" devoted to botany, zoology, and physics (Persson 1974). All of the insects were included in the first part of volume 2, published serially (Virgin 18581868). The taxonomy of the beetles was studied by C. H. Boheman $(1858,1859)$, resulting in the description of many new species. For a history of the voyage, itinerary, and comments on entomological results, see Persson (1974).

Among the new taxa, Boheman (1858) described a new genus and species that he called Aulacothorax exilis from Tahiti and placed it in Scydmaenidae (now Staphylinidae: Scydmaeninae). The description is accompanied by a relatively clear illustration (Fig. 4) of the beetle habitus. Sharp (1874), while looking at the illustration, recognized that this beetle did not belong to Scydmaeninae, but he did not transfer it. He suggested that it may be placed in either Anthribidae, Bruchidae (now Chrysomelidae: Bruchinae), or Urodontidae (now Anthribidae: Urodontinae). Since then, A. exilis has not been treated in the Scydmaeninae literature nor included in any other beetle family and, therefore, disappeared from the entomological literature altogether.

While studying Chrysomelidae in Naturhistoriska Riksmuseet, Stockholm, Jan Bezděk discovered the type specimen of $A$. exilis in a box with unsorted Chrysomelidae. Because there is no evidence in the original description that Boheman had additional specimens, we treat this specimen as the holotype. We conclude that it is congeneric with the alticine genus Orthaltica Crotch, 1873, and because Aulacothorax is the oldest available name we here replace Orthaltica with it.

\section{Material and Methods}

While redescribing $A$. exilis, we used the same general format and character set as in Prathapan et al. (2013). We refrained from dissecting the only known specimen (female) of this species since it appears fragile. The specimen is also covered with 
glue, so the ventral side of the beetle body and parts of the legs were not available for observation. Descriptive terminology follows Konstantinov (1998).

Observations and measurements were made with a Zeiss Stemi SV11 Apo microscope. Digital photographs were taken with an Axio Zoom V16 microscope with a AxioCam HRC digital camera attached to it.

\section{Aulacothorax Boheman, 1858} (Figs. 1-4)

Aulacothorax Boheman 1858: 35 (type species Aulacothorax exilis Boheman, 1858, by monotypy).

Orthaltica Crotch 1873: 69 (type species Crioceris copalina Fabricius, 1801, by subsequent designation of Scherer 1974). New synonymy.

Leptotrix Horn 1889: 249 [not Menge 1868 (Arachnida)] (type species Haltica recticollis J. L. LeConte, 1861, by monotypy). New synonymy.

Micrantipha Blackburn 1896: 88 (Micrantipha paradoxa Blackburn, 1896, by monotypy). Reid 1990: 205 (synonymy). New synonymy.

Livolia Jacoby 1903: 15 (type species Livolia sulcicollis Jacoby, 1903, by subsequent designation of Scherer 1974). Scherer 1974: 66 (synonymy). New synonymy.

Leptotrichaltica Heikertinger 1925: 68 (replacement name for Leptotrix Horn, 1889). Scherer 1974: 66 (synonymy). New synonymy.

Micrepitrix Laboissière 1933: 205 (type species Micrepitrix coomani Laboissiere, 1933, by monotypy). Scherer 1971: 10 (synonymy). New synonymy.

Serraticollis B. White 1942: 17 [type species Serraticollis rhois B. While, 1942 (= Orthaltica recticollis J. L. LeConte, 1861), by original designation]. Arnett 1963: 938 (as synonym). New synonymy.

Epithrella Medvedev 1993: 17 (type species Epithrella philippina Medvedev, 1993, by original designation). Konstantinov and Prathapan 2008: 406 (synonymy). New synonymy.

Livoliella Medvedev 1997: 100 (type species Livoliella luzonica Medvedev, 1997, by original designation). Konstantinov and Prathapan 2008: 406 (synonymy). New synonymy.

\section{Aulacothorax exilis Boheman, 1858}

(Figs. 1-4)

Type Material. Holotype: + , "Taiti. [= Tahiti] [white label, printed] // Kinb. [= Kinberg (collector), white label, printed] // Aulacothorax exilis Bhn. [white label, Boheman's handwriting]", (deposited in Naturhistoriska Riksmuseet, Stockholm).
Redescription. Body length $1.52 \mathrm{~mm}$, width $0.67 \mathrm{~mm}$. Body pale brown with antennae and legs paler. Head: Vertex with 10 long setae (5 on each side) including 4 setae situated along orbital sulcus. Supracallinal sulci straight, forming acute angle with each other. Supraorbital sulcus short, shallow. Orbital sulcus long, deep. Suprafrontal sulcus poorly developed, appearing as frontal ridge merging with antennal calli. Antennal calli narrow, separated by sharp midfrontal sulcus, without setiferous pores. Frontal ridge parallel-sided, narrow, reaching anterofrontal ridge. Anterofrontal ridge slightly wider than frontal ridge, evenly high, sloping abruptly towards clypeus. Labrum as wide as space between outer edges of eyes. Setiferous pores on dorsal surface of labrum small, not possible to count. Relative proportions of antennomeres as follows: 13:13:7:8:10:8:10:10:10:10:15. Pronotum: Widening anteriorly, widest slightly anterior to middle, $1.35 \mathrm{X}$ as wide as long. Sides slightly uneven with small denticles bearing long setae. Antebasal transverse impression well-developed. Pronotal surface densely covered with large punctures, their diameter about as large as distance between punctures. Elytra: Sparsely and unevenly pubescent, with setae visible along lateral margin. Elytral punctures arranged in striae placed in shallow grooves. Stria 7 incomplete, not reaching elytral base. Humeral calli well-developed. Legs: Pro- and mesotibiae lacking spurs. Claw appendiculate.

\section{Discussion}

The taxonomy of Orthaltica and its synonyms was discussed by Scherer $(1971,1974)$ and Konstantinov and Prathapan (2008). While assessing the taxonomic relationships of Orthaltica with Epithrella and Livoliella, we considered the following combination of character states as diagnostic for it (Konstantinov and Prathapan 2008): vertex shiny, covered with up to 14 symmetrically placed punctures each bearing a long, erect seta; antennal calli narrow, oblique, and connected with the appearance of a "V"; anterofrontal ridge low, much lower than frontal ridge; fascial part of head short; pronotum covered with large and deep punctures, their diameter as great as distance between them; lateral margin of pronotum with small projections bearing characteristic setiferous pores; pronotal anterfrontal collosity short, facing antero-laterally with setiferous pore in its middle; procoxal cavities closed behind; elytral punctures regularly arranged, interstices more or less convex, epipleuron subvertical, humerus strongly raised, with depression posteriorly; metafemur without apical spur. Aulacothorax shares all of these character states and, therefore, is undoubtedly congeneric with Orthaltica. 

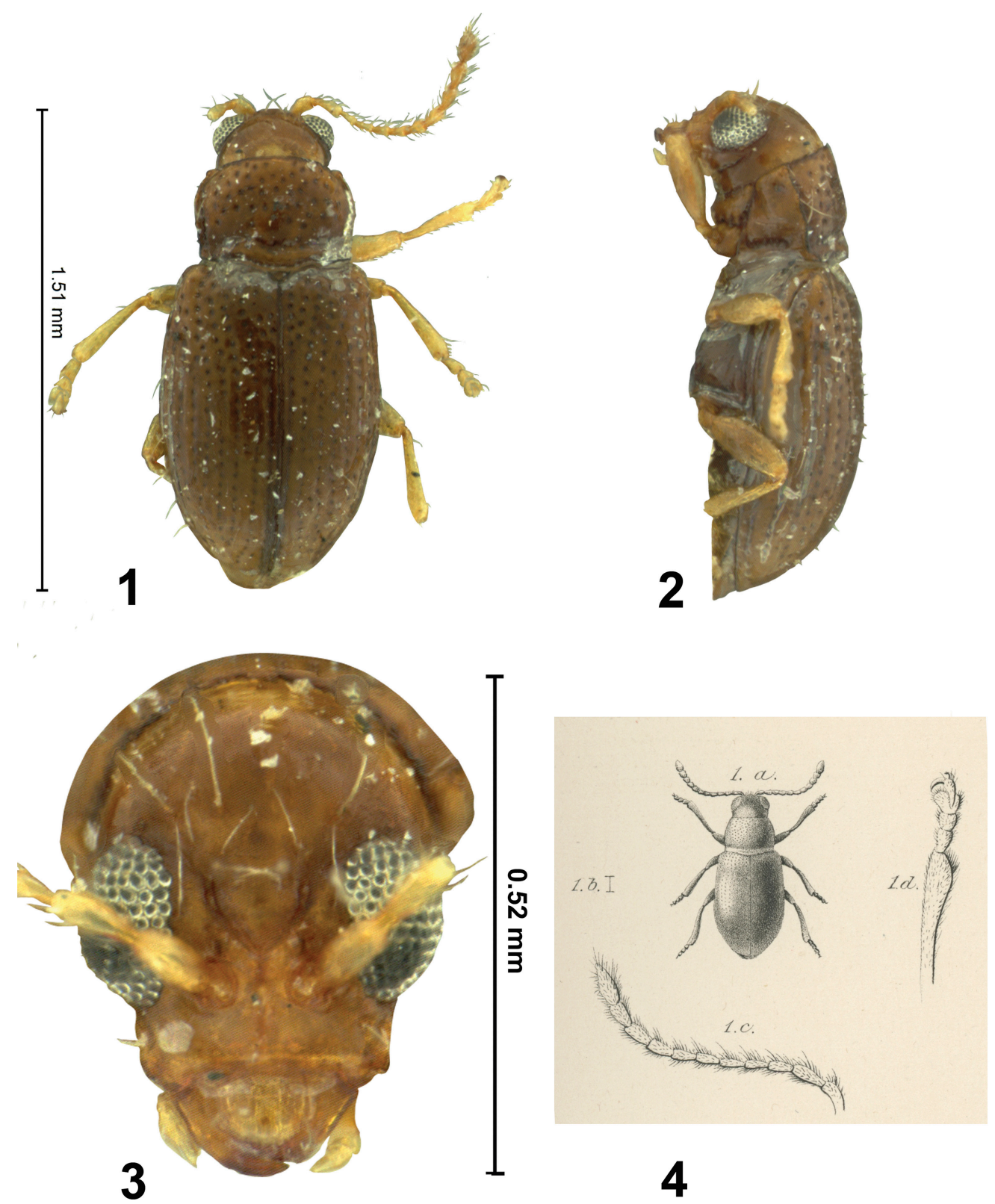

Figs. 1-4. Aulacothorax exilis. 1) Dorsal habitus; 2) Lateral habitus; 3) Head, frontal view; 4) Original illustration (Boheman 1858, plate I, fig. 1).

As currently understood, there are 48 species of Aulacothorax in the world. Among biogeographic regions, they are distributed as follows: Afrotropical Region - two species; Australian Region - five species; Nearctic Region - five species; Oriental Region - 35 species; and a single species in the Palearctic - Aulacothorax arabica (Medvedev, 1997) from Saudi Arabia. Although there are some doubts about the actual geographic origin of some species described by Boheman in 1858 and 1859, it is very possible that Tahiti is the true type locality for A. exilis. Our preliminary work on a world flea beetle species database lists only three species of flea beetles known to be described from Tahiti.

Aulacothorax species that were available for our study [Aulacothorax bakeri (Konstantinov, 1995), 
Aulacothorax borneoensis (Konstantinov, 1995), Aulacothorax coomani (Laboissiere, 1934), Aulacothorax copalina (Fabricius, 1801) - the type species of Orthaltica, Aulacothorax melina (Horn, 1889), Aulacothorax mindanaoensis (Konstantinov, 1995), Aulacothorax minutiuscula (Csiki, 1939), Aulacothorax okinawana (Gressitt and Kimoto, 1966), Aulacothorax orientalis (Konstantinov, 1995), Aulacothorax pahangi (Konstantinov, 1995), Aulacothorax recticollis (LeConte, 1861), Aulacothorax syzygium (Prathapan and Konstantinov, 2013), and Aulacothorax terminalia (Prathapan and Konstantinov, 2013)] show that $A$. exilis is clearly more similar to the Oriental species than the Nearctic species. Many Oriental species [e.g., A. minutiuscula, A. okinawana, A. pahangi] share a number of character states: relatively small, light or dark brown body; vertex with 6-12 setiferous pores; small denticles on the sides of the pronotum; and incomplete $7^{\text {th }}$ elytral stria. As the result of comparing A. exilis with species in the US National Museum of Natural History collection, we consider the following A. exilis characters as unique: vertex with 10 long setae (five on each side) including four setae situated along orbital sulcus; supracallinal sulci straight, forming acute angle with each other; supraorbital sulcus short, shallow; relative proportions of antennomeres 13:13:7:8:10:8:10:10:10:10:15.

\section{ACKNOWLeDgments}

This research received support from the Synthesys Project SE-TAF-3534 financed by the European Community - Research Infrastructure Action under the Seventh Framework Programme. Special thanks are due to Johannes Bergsten for his assistance during Jan Bezděk's studies at the Naturhistoriska Riksmuseet Stockholm.

Mention of trade names or commercial products in this publication is solely for the purpose of providing specific information and does not imply recommendation or endorsement by the USDA; the USDA is an equal opportunity provider and employer.

\section{References Cited}

Arnett, R. H. 1963. The Beetles of the United States. The Catholic University of America Press, Washington, DC.

Blackburn, T. 1896. Further notes on Australian Coleoptera with descriptions of new genera and species. Transactions of the Royal Society of South Australia 20 (1895-1896): 35-109.

Boheman, C. H. 1858. Coleoptera. Species novas descripsit [pp. 1-112, pls I-II]. In: Kongliga Svenska Fregatten Eugenies Resa omkring jorden under befäl af C. A. Virgin, ären $1851-1853$. Vetenskapliga Iakttagelser pa H. M. Konung Oscar den Förstes befallning utgifna af K. Svenska
Vetenskaps Akademien. II. Zoologi. 1. (C. Virgin, editor). P. A. Norstedt \& Söner, Stockholm, Sweden.

Boheman, C. H. 1859. Coleoptera. Species novas descripsit [pp. 113-218, pl. III]. In: Kongliga Svenska Fregatten Eugenies Resa omkring jorden under befäl af C. A. Virgin, ären 1851-1853. Vetenskapliga Iakttagelser pa H. M. Konung Oscar den Förstes befallning utgifna af K. Svenska Vetenskaps Akademien. II. Zoologi. 1. (C. Virgin, editor). P. A. Norstedt \& Söner, Stockholm, Sweden.

Crotch, G. R. 1873. Materials for the study of the Phytophaga of the United States. Proceedings of the Academy of Natural Sciences of Philadelphia 25: 19-83.

Heikertinger, F. 1925. Die Halticinengenera der Palaearktis und Nearktis. Bestimmungstabellen. Koleopterologische Rundschau 11(3/4): 49-70.

Horn, G. H. 1889. A synopsis of the Halticinae of boreal America. Transactions of the American Entomological Society 16: 163-320.

Jacoby, M. 1903. A further contribution to our knowledge of African phytophagous Coleoptera, Part II. Transaction of the Entomological Society, London 1903: 15

Konstantinov, A. S. 1998. Revision of the Palearctic species of Aphthona Chevrolat and cladistic classification of the Aphthonini (Coleoptera: Chrysomelidae: Alticinae). Memoirs on Entomology International, Associated Publishers, Gainesville, FL.

Konstantinov, A. S., and K. D. Prathapan. 2008. New generic synonyms in the Oriental flea beetles (Coleoptera: Chrysomelidae). The Coleopterists Bulletin 62(3): 381-418.

Laboissière, V. 1933. Descriptions de trois nouveaux Galerucini du Tonkin. Bulletin du Muséum national d'histoire naturelle (ser. 2) 5: 203-208.

Medvedev, L. N. 1993. Alticinae of the Philippine Islands (Coleoptera, Chrysomelidae). Part 2. Russian Entomological Journal 2(5-6): 11-32, 2(3-4): 41-58.

Medvedev, L. N. 1997. New and interesting Chrysomelidae (Coleoptera) from the Philippines collected by Dr. M. Sato. Japanese Journal of Systematic Entomology 3(1): 99-104.

Persson, P. I. 1974. "Eugenies resa". Localities, dates and labels of the insects collected during the voyage around the world by the Swedish frigate "Eugenie" in the years 1851-1853. Entomologisk Tidskrift 92: $164-172$.

Prathapan, K. D., A. S. Konstantinov, K. M. Shameem, and A. P. Balan. 2013. First record of leaf-hole shelters used and modified by leaf beetles (Coleoptera, Chrysomelidae), with descriptions of two new Orthaltica Crotch species from southern India. Zookeys 336: 47-59.

Reid, C. A. M. 1990. Micrantipha Blackburn, a synonym of Orthaltica Crotch (Col., Chrysomelidae). Entomologist's Monthly Magazine 126: 205-206.

Scherer, G. 1971. Das genus Livolia Jacoby und seine umstrittene stellung im system. Eine taxonomische-zoogeographische-evolutionistische studie (Coleoptera-Chrysomelidae-Alticinae). 
Entomologische Arbeiten aus dem Museum G. Frey 22: 1-37.

Scherer, G. 1974. Review of North American species of Orthaltica with new generic synonymy (Coleoptera: Chrysomelidae: Alticinae). The Coleopterists Bulletin 28(2): 65-72.

Sharp, D. 1874. Note on Aulacothorax exilis, Boheman. Entomologist's Monthly Magazine 11: 137.

Virgin, C. (editor). 1858-1868. Kongliga Svenska Fregatten Eugenies Resa omkring jorden under befäl af C. A. Virgin, ären 1851-1853. Vetenskapliga
Iakttagelser pa H. M. Konung Oscar den Förstes befallning utgifna af K. Svenska Vetenskaps Akademien. II. Zoologi. 1. Insecta. P. A. Norstedt \& Söner, Stockholm, Sweden.

White, B. E. 1942. A new genus and species of Coleoptera (Chrysomelidae) from the southwestern United States. Entomological News 53(1): 16-21.

(Received 17 March 2017; accepted 3 October 2017. Publication date 22 December 2017.) 